\title{
The Compositional Making and Geographic Itinerancies of the Chansons de Roland During the Early and Late Middle Ages
}

\author{
Mirabile Paul \\ Department of Western Languages, Heilongjiang International University, Haerbin, China
}

Email address:

mirabile_paul@hotmail.fr

\section{To cite this article:}

Mirabile Paul. The Compositional Making and Geographic Itinerancies of the Chansons de Roland During the Early and Late Middle Ages. International Journal of European Studies. Vol. 3, No. 1, 2019, pp. 52-66. doi: 10.11648/j.ijes.20190301.19

Received: March 7, 2019; Accepted: April 12, 2019; Published: June 26, 2019

\begin{abstract}
The author examines the centripetal compositional forces and the itinerant centrifugal forces that produced the Chanson de Roland and diffused the Chansons de Roland since its remote Nordico-Germanic and Gallo-Roman origins to their wide-scale geographic settlings in western mediaeval Europe. To demonstrate this dual force, the author traces the Figure of a sand-glass which visualizes the first migrating compositional flow from the wide plains of Scandinavia, through sedentarized Gaul and on to the battlefield of Roncevaux Pass, and the second propagating flow from the oldest extant Oxford version to the eight variants which, although scattered over different countries, are very much inter-related since they all drew inspiration from Roland's heroic death at the eventful battle of Roncevaux. The nine versions of the Chanson de Roland founded the mediaeval western European poetic koinê.
\end{abstract}

Keywords: Sand-glass, Centripetal Compositional Forces, Centrifugal Itinerant Forces, Poetic Koinê, Orature

\section{Introduction}

\section{Centripetal and Centrifugal Forces}

The Middle Ages of western Europe have been called the 'Dark Ages' by many an historian. And there is indeed some truth in this sobriquet. However, all ages have their 'dark side'; it suffices to recall to memory the one we have just left behind nineteen years ago!

Other historians, philologists and linguistics, on the contrary, have brilliantly revealed the 'bright' side of the Middle Ages of western Europe, enlightening us, for example, on the theological and philosophical works of Saint Augustin, Saint Thomas of Aquinas, William of Ockham, Duns Scotus, Moses ben Maimon and Ibn Rushd (Alverroes); on the extraordinary architectural gems of mediaeval Europe: cathedrals, castles and cloisters; on the 'imagiers' or the makers of the marvelous stained glass windows; on the lyric poetry of the trouvères of northern Europe or the troubadours of southern Europe, and that of the Mozarabic jarchas. In sum, the mediaeval artist-artisans and writers of these works of art laid the cultural foundation of what has become today Europe; namely, a cultural unity wrought from the particular values of all her very distinct contributors. These binding values have for their fount the Middle Ages.

I have followed in the footsteps of these historians and philologists for whom the Middle Ages of western Europe not only deserve to be regarded as a period of contribution to the Humanities, but more important still, should serve as a model of how the myriad particularities of variegated cultures, over the centuries, have forged a unified religious, philosophical and literary cultural identity. It has been my research into the particularities of western European mediaeval cultures, by dint of the examination of their respective epic tales, that has convinced me of this mediaeval unity, and its unbroken cohesion to our present day.

My investigations have been primarily in the field of literary discourse, and to demonstrate the unity of mediaeval European discourse I have studied the French epic tale, the Chanson de Roland or the Song of Roland, whose oldest written composition dates from the eleventh century (1060?). For the Chanson de Roland is precisely that mediaeval composition whose oral and written verses travelled well beyond the confines of French speaking communities from France to England and to Spain; from France to Germany and 
to Italy ! Due to this wide geographical and literary unfolding and to the broad reception of its discursive purport, I believe the Chanson de Roland to be the first vernacular literature of western mediaeval Europe...

Surely, the influence of the Chansons de Roland on western European cultures during the Late Middle Ages is one of the most remarkable aspects of mediaeval oral and written mobility. Their oral execution by bards and minstrels was recited aloud before assemblies, and their written compositions by scribes read by the educated throughout mediaeval western Europe.

There are eight mediaeval versions of the Chanson de Roland all of which vary in length, in technique (poetic or narrative), in linguistic variations and political motivation. The versions are housed in France (Paris, Châteauroux, Lyon, Lorraine), in Northern Italy (Venice IV and Venice VII) and in England (Oxford, Cambridge). An early German translation and adaptation (the Konrad adaptation) is also a result of the centrifugal forces as are the composition of the mediaeval Spanish epic tale El Cid, the 100-verse Cantar de Roncevalles and the 1,410 verse poem Rollan a Saragossa, which drew inspiration from the historical presence of Roland and Charlemagne in mediaeval Spain, and to a certain extent from the bardic narratological technique and poetic structure of the Chansons de Roland that were sung and recited along the Way of St. James.

The widespread geographic itinerancy of the Chansons de Roland appears in their very compositional construction and narrative drama: the oldest extant manuscript is the Oxford version, an orally executed strophic poem later to be written down in Anglo-Norman, hence in mediaeval England. However, the main dramatic location of the poem is in the Spanish Pyrenees, where Roland's rear-guard was ambushed by Vascones, thoroughly routed and Roland killed in the battle along with eleven other of Charlemagne's exemplars. That the Vascos or the Vascones (Basques) were historically those who attacked Roland's rear-guard has been contested. It is outside the scope of this article to summarize the enormous erudition on this subject. In the Songs of Roland the attackers are named Saracens or Moors due to the events of the Crusader wars of the eleventh, twelfth and thirteenth centuries. Yet, much of the song's poetic verve and themes derive from a Nordico-Germanic fount; that is, a commingling of traditions and languages of the migrating Scandinavian, Salic (Merovingian) and Ripuarian (Carolingian) peoples with those traditions and languages of the sedentarized Gallo-Romans of mediaeval France (Francia).

The very multicultural compositional forces of all the Chansons de Roland, and their wide recited and written variants, stamp the poems, with all due reserve, as the first vernacular 'European' poetic work (s) of any wide-scale importance. For indeed, each version is a blend of the other, either copied from manuscripts housed in monasteries, or heard from wandering bards, all of which expressing their own regional linguistic and narrative characteristics with so many diverse interpolations, so many semantic or syntaxic substitutions, so many orthographic variations of dialect or language. For these reasons, no longer is it custom to say the Chanson de Roland, but the Chansons de Roland, and thereby situate the 'French national epic' within a European ambit. The Chanson de Roland, the first vernacular European epic, seems more European than, for example, Beowulf in spite of its hybrid Scandinavian, English and Latin forms and traditions, Das Nibelungenlied in spite of its compound of Latin, Scandinavian and Germanic traditions, and El Cid in spite of an admixture of Latin, Spanish and French narratological techniques and themes because these mediaeval epic tales, albeit hybrid, remained within their own geographic confines as can be adduced by the scarcity of their versions. There is only one version of Beowulf, two versions of El Cid, both housed in Spain, and two versions of Das Nibelungenlied, the oldest being of Scandinavian stamp (eighth century) and the second of German origin composed in the eighth century. Both are housed in Germany.

The melding of such diverse discourses over several centuries of community cohabitation, and whose result was the hybrid composition of all the Chansons de Roland resulted from the historic compound of centripetal and centrifugal forces. These forces constituted a movement that created both the composition of the song and its itinerant mediaeval adventure. I insist on the adjective 'mediaeval' for I shall not treat such works as Ariostos's Rolando Furioso, nor the more contemporary productions of Roland's poems.

Indeed, centripetal forces drew together and inter-weaved the heterogeneous linguistic and ethnic elements that forged the Chanson de Roland into an assimilated unity. The centrifugal forces then rent the woven tissue into so many fragments, spreading them over a vast geographic zone where they, too, underwent further coalescent processes with the linguistic materials and political injunctions afforded them in those regions. This poetic spate outwards from the oldest versions of the Chanson de Roland -that is, the Oxford version and Venice $I V$-, and the gradual compiling of the other vernacular versions from them in western Europe represents the result of centuries of centripetal and centrifugal dynamic tension, whose dialectic movement has structured and restructured the European historical and literary landscape. My argument here is that the result of the centripetal forces during the Early Middle Ages in western Europe, fragments of songs of Roland and Charlemagne were forged into a single poem, and the result of the centrifugal forces during the Late Middle Ages many songs of Roland and Charlemagne were compiled, but whose inter-connected unity, either by theme or by form, created a western European mediaeval poetic koinê. And although the dialects and political motivations differ from version to version, Roland's, Charlemagne's, Ganelon's, Olivier's and Turpin's heroic or tragic discourses, and the gestures and acts which support those discourses, constitute the symbiotic foundation of the koinê.

The mediaeval centripetal and centrifugal forces that forged and transmitted the Songs of Roland, and thereby shaping the mediaeval poetic koinê, cast an interesting light 
on just how extraordinary the chivalric narrative of a single battle in the heart of the Pyrenees became the first piece of vernacular literature of mediaeval Europe to travel so widely; the first narration thought out, recited then written down in an autochthonous tongue, which consequently effected a rupture of the dominant and exclusive Greek-Latin literary continuum that had begun with Homer's and Virgil's poetic works. The Song of Roland is neither a translation nor an adaptation of either a Greek or a Latin poem, as for example, La Vie deSaint Léger, La Cantilène de Sainte Eulalie, la Vie de Saint Alexis, all translations from Latin. As to the Serments de Strasbourg, they can hardly be reckoned as a vernacular piece of literature ; it is a work wrought from a mediaeval, vernacular language, a language suffused with the many cultural discourses that were evolving in western Europe. In this sense, autochthonous, too, are Beowulf, El Cid and Das Nibelungenlied, all poems thought out, recited then written down in their vernacular tongues.

It goes without saying, however, that mediaeval poetry drew inspiration from a Greek and Latin literary tradition. And this inspiration has left its traces in the Chansons de Roland. None the less, the Chansons de Roland drew much poetic and political inspiration from the vernacular founts that were welling up throughout western Europe. And it is by these welling founts that I shall begin my survey of the composition of the Song of Roland (Oxford version). [10]

\section{Results}
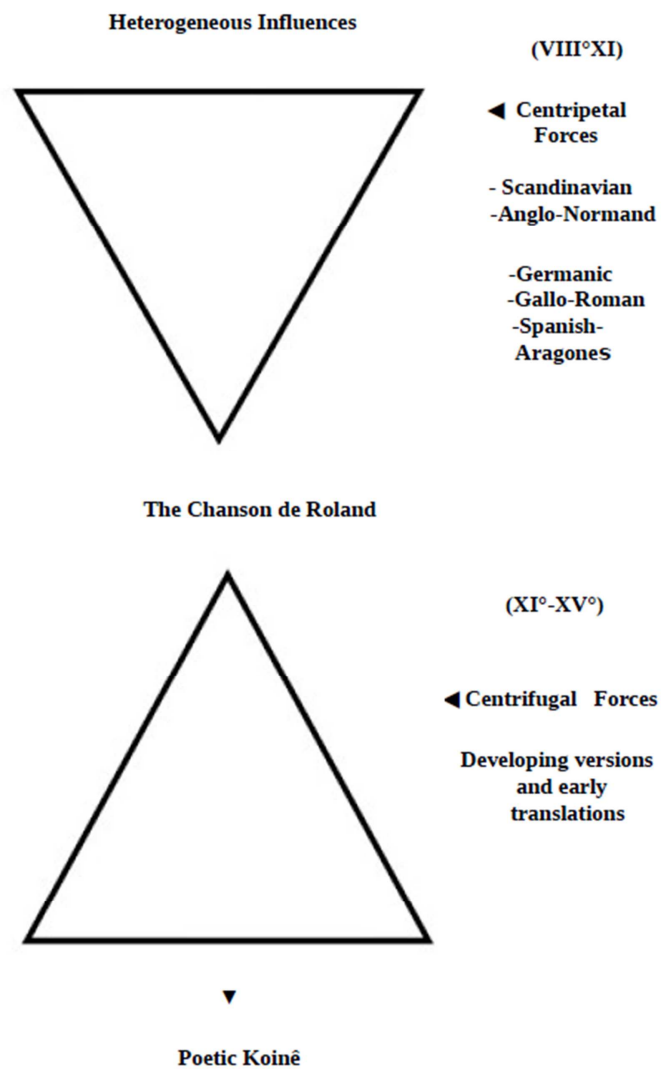

(The Chansons de Roland of the western Koinê)

Figure 1. Roland's Sand-glass.
The results of the centripetal and the centrifugal forces can be viewed by the figure of a sand-glass. They demonstrate, iconically, the binary tension in the composing of the Song of Roland and of the Songs of Roland of the poetic koinê. As can be seen by the drawn figure, the upper triangle (or pyramid) of the sand-glass represents the wide aperture or mouth through which the heterogeneous elements of Scandinavian, Nordico-Germanic, Anglo-Norman, GalloRoman and Spanish-Aragonese penetrate and are assimilated as they flow geographically down to the small hole of the funnel or the tip of the triangle, that is Roncevaux. This lower tip, thus, represents the narrative landscape of the Chanson de Roland as it is depicted in the Oxford version. The upper tip of the lower triangle that touches the tip of the upper triangle shows the Chanson de Roland flowing towards the broad mouth of the periphery in its centrifugal movement. This periphery depicts the mediaeval western European poetic koinê.

\section{Discussion}

\subsection{The Centripetal Compositional Forces}

Briefly, centripetal forces move from the general to the particular as if they flowed through a funnel, beginning at a wide aperture then narrowing down to a centre. These forces transport disparate, heterogeneous elements that little by little, as they flow, are integrated and assimilated into a homogeneous unity when they reach the small hole of the funnel. However, contrary to certain assertions, these assimilated elements have not been emptied of their original properties during the assimilating flow; each element retains its basic property or characteristic, for if not, it would be impossible to analyse the composition of the blend, and thus impossible to reproduce its original properties. I call this assimilating process and its symbiotic fusion dialectical monism. In the Middle Ages it was called 'mixtorum alterorum unio'. [1]

Concretely, in the case of the composing of the Chanson de Roland, it is the Anglo-Norman, Nordico-Germanic, Gallo-Roman and Spanish-Aragonese ethnic and linguistic elements that have been introduced and assimilated in the historical process of the making of the poem. Each element had its role to play, articulated by its own cultural discourse, and which can readily be analysed by a philological study of the text since each element has preserved its original property. I shall thus begin with the Anglo-Norman influences for this is the dialect in which the oldest version was recited and written.

\subsection{Anglo-Norman Centripetal Forces}

The Oxford version of the Chanson de Roland was discovered at the Bodleian Library of Oxford by the French philologist Francisque Michel (1809-1887) in 1835. The text dates roughly between 1060 and 1070 . It is made up of 4,002 assonanced verses, [2] and judging by the extraordinary number of repeated formulae it is of oral fount. It is little 
wonder that the oldest text is located in England for most probably it represents the first hoary verses of a song that was sung by Duke William of Normandy's warriors as they crossed the 'mer salse' (salty sea) in 1066 to attack Harold, the usurper of the English throne:

'Taillefer, qui mult bien chantout

sor un cheval qui tost alout,

devant le duc alout chantant

de Karlemagne et de Rolant

et d'Oliver et des vassals

qui mourent en Rencefals...' [3]

'Taillefer, who sang so well

rode out on horseback, and soon went

before the duke singing

of Charlemagne and of Roland

and of Olivier and of the vassals

who died at Roncevals...' (verses 8035) (My translation)

These verses have been extracted from Wace's Roman de Rou (1160). They describe the enthusiasm of William's warriors sailing towards Pevensey in anticipation of battle. Wace also relates that in Guillaume de Malmesbruy's De Gestis regum Anglorum, written in 1125, the chronicler mentions that a Cantilena Roland was sung at the Battle of Hastings during the din of combat.

That these verses were sung by William's doughty warriors, and that the future Song of Roland was recited by Norman and Anglo-Norman minstrels, then copied by AngloNorman scribes is perfectly congruous with the historical reality of mediaeval England between the eleventh and the thirteenth centuries, where Norman and French were the prevalent written languages. It should not come as a great surprise that the first vernacular text in French was written and discovered in England: was not the first French grammar composed in England in the Anglo-Norman dialect, L'Aprise de français by Walter de Bibbesworth in 1290 ?

I have no intention of listing all the Anglo-Norman spelling traits recorded in the Oxford version of the Chanson de Roland as read in Gérard Moignet's running footnotes. Furthermore, by enumerating these etyma I make no pretense to originality; they are merely linguistic matter which had been carried along the centripetal flow of the sand-glass, and thus comprise an important component of the Chansons de Roland of the western koinê. For indeed there are quite a few semantic features of the Anglo-Norman dialect as recorded in the Oxford version that serve as resonant examples of Roland's European dimensions. I shall proceed by the order of the verses. [4]

In verse 241 the Anglo-Norman form 'soürs' (in Old French seürs) meant 'sure, assured': 'U par ostage vos en voeilt faire soürs' (Since he wants to assure you with hostages). Its adverbial form 'soürement' is read in verse 790: 'surely, assuredly'.

In verse 489 , we read the word 'remembre' which meant in Old French 'souvenir, rappel': 'Que me remembre de la dolur e de l'ire' (That I should remember his pain and his anger).
The verbal form is 'remembrar'. The Modern French 'remembrance' is rarely employed.

The Anglo-Norman etymon 'remeines' in verse 600 , 'remain' in English was lost in the evolution of the French language. In the Song of Roland it meant 'cease to exist': 'Tere Major remeindreit en repos'. (The soil of our grandfathers would remain in peace).

'Cuard' is read in verse 888: "Pur tut l'or Deu ne volt estre cuard" (For all the gold of God he does not want to be a coward). It evolved into the English 'coward' and is still employed in Modern French (couard), albeit in learned literature.

Similarly with the much used etymon 'damage', which in Modern French became 'dommage'. In verse 1102, 'Fust i li reis, n'i oüssum damage' (If the king were there, we would not succumb to such a massacre). Its mediaeval meaning was much stronger than 'damage': 'massacre, slaughter'.

In verse 1005, we read: 'Granz est la noise, si l'oirent Franceis' (Great is the noise, the French heard it), where the Anglo-Norman 'noise' is translated as 'bruit'. In Modern French there remains one expression with 'noise': 'Il cherche des noises': 'He's looking for trouble'.

'Faiture', too, is an interesting etymon of Anglo-Norman stamp: 'Si li trenchat les oilz e la failure,' (v. 1328) (he severs his eyes and face). It meant 'figure' (face) in Old French, and evolved into 'feature' in Modern English. In Middle French it also signified 'a model of something made, produced or created'. The form no longer exists in Modern French.

Neither is there a trace in Modern French of the etymon 'culvert': 'Respunt Rollant: Vencut est le culvert.' (Roland replies: 'The wretch is defeated' (v. 1394), interpreted as 'coward, traitor, wretch'. In Middle French there existed the form 'culvert' which meant 'serf' or 'a wretched, ignoble person'. It may be the origin of the English word 'culprit'.

'Hastive' in verse 1653: 'La bataille est merveilleuse e hastive' (The battle is marvelous and hastens on) evolved into 'hasty'. The weakening of the phoneme [s] after a vowel during the XIII ${ }^{\circ}$ century in France explains the substitution of the letter 's' by the accent circumflex in Modern French: 'hâtif'. The same evolution occurred with the word 'fest $>$ fête' (v. 37), whereas in English the 's' was retained 'feast. It is interesting to point out in this respect the evolution of AngloNorman words beginning with the palatal [k], which during the thirteenth century were palatalized in French: [j]. For example, kastel $>$ château, cambre $>$ chambre, $\mathrm{K}(\mathrm{C}) \operatorname{arl}(\mathrm{es})>$ Charles, whereas in English the incipit voiceless palatal was retained: castle, camera (a room), and whose derivative form is 'camrade' 'chamber mate'. [5]

Another interesting etymon to examine is 'pargetent' read in verse 2634: 'La sus amunt pargetent tel luiserne' (they (lanterns) cast afore and above such light), where it is interpreted as 'to cast, throw'. The Old French verbal form 'pargeter' meant 'to project, to scatter'. In English, according to the Reverand Walter W. Skeats' etymological dictionary, it is indeed of Anglo-Norman origin, and whose Middle English form 'parget' meant 'plaster' from the Anglo-Norman verb 'projeter' 'to replaster'. For example, 'to replaster a wall'. 
Hence, the expression 'a pargetted wall'. [6]

In verse 3006, we read the etymon 'cuntenances': 'Quant Carles veit si beles cuntenances,' (When Charles sees their fine appearances) interpreted in French as 'allure'. The Middle English form is 'cuntenaunce'. In Modern French 'contenance' means 'attitude, expression'. For example,'faire bonne contenance' : 'keep cool or calm'

In verse 3805: 'Nen ad celoi niel graant e otreit' (Not one would grant or approve it), the etymon 'graant' has evolved into the Modern English 'grant'. The verbal form was 'grëanter'. It has left no trace in Modern French.

The Anglo-Norman 'guarantir' is read in verse 3836: 'Mun jugement voel sempres guarantir' (I want my judgment supported). The Old French form is 'garant', the incipit consonant cluster 'gu-' having been retained in AngloNorman due to the Germanic influence of English, influence which also created the doublet 'warrantie, warrant', etc.

The Anglo-Norman etymon 'pleges', read in verse 3846: "Dist li empereres: 'Bons pleges en demant.' (The emperor said: (I want a pledge of faith) is interpreted as 'garant', which remained in English 'pledge'. No derivative form is found in Modern French.

As to the etymon 'cambre' 'chamber, room' in verse 3993: 'Culcez s'est li reis en sa cambre voltice' (the king lay down in the vaulted chamber), there is uncertainty whether it be of Anglo-Norman or Provençal stamp. Similarly with 'reregarde' (v. 742): 'Kar me jugez ki ert en la reregarde' (appoint me as the one who will be at the rear-guard), which may or may not be of Anglo-Norman origin: The Old French morpheme 'rere' meant 'to raze, to shear', which here, though, is bereft of meaning. The adjectival form, too, 'rere' meant 'rare'. However, there did exist an adverbial form 'riere', which signified 'behind', and might have served to form compound words.

I shall now sum up several mediaeval Spanish centripetal forces prominent in the drama of the Song of Roland, followed by a short exposition of the centrifugal forces which not only evince the popularity of the poem in mediaeval Spain, but more importantly, out of whose poetic form gave rise to $\mathrm{El} \mathrm{Cid}$, and whose dramatic plot to the Cantar de Roncevalles and Rollan a Saragossa.

\subsection{Mediaeval Spanish Centripetal and Centrifugal Forces}

Mediaeval Spain was the background of the historical battle which took place at Roncevaux Pass in the Pyrenees on August 15th, 778. The precise topographic location of the famous battle has been the subject of discussion. [7] Who 'really' ambushed Charlemagne's rear-guard commanded by the governor of the Breton March, Roland, as his warriors retreated from their defeat at Pamplona by the Arabs is a subject that remains open to debate, a subject that goes well beyond my competence, and much too vast to be treated in the scope of this essay. [8] The rout of Charlemagne's rearguard and death of Roland must have had a large impact on the Spanish mediaeval mind for at the monastery of San Millán de la Cogalla near to Burgos, one of the many monasteries that dot the Camino de Santiago (Way of St.
James), a document written in Latin dating from the eleventh century (1070-1075) -Nota Emilianense 39- attests in some detail Roland's death at Roncevaux: 'In Rozaballes a gentibus Sarrazenorum fuit Rodlane occiso', and the document names several heroes who fought alongside Roland: Bertrand Ogierà-l'épée-court, Guillaume-au-courbe-nez, Olivier and the Bishop Turpin. It also mentions Charlemagne's entrance into Zaragoza (Cesaragusta), and praises his courageous warrior (belligerator fortis) of the rear-guard (posterum), Roland: '...ut rodlane belligerator fortis cum suis posterum ueniret.. ' [9].

This remarkable document bears witness not only to Roland's ubiquitous presence in mediaeval Spain but to the widespread popularity of the historical battle that slowly but steadily weaved the many legends that spiralled out of the battle, deploying the event in polyphonic hues and tinges throughout western Europe. The centripetal movement from the Roncevaux Pass in the eighth century, through Normandy and to the battlefields of England in the eleventh and twelfth centuries is truly emblematic of mediaeval mobility and trans-national intercourse!

Joseph Bédier stressed that the Way of St. James had been the principal vector of oral and written transmission of the Chanson de Roland, recited by pilgrims as they advanced towards Compostella. [10] As vehicles of communication, pilgrimage roads in the Middle Ages favoured the reciting of stories, especially those of heroic combat. Stories that would become veritable legends after generations of bardic reporting, of layered discursive elaboration, of interpolated scribal eagerness. There is no doubt that Roland's death benefited from this major pilgrimage way between Northern Spain and France, the Roncevaux Pass acting as both catalyst and channel. It is, of course, no coincidence that the Nota Emilianense 39 was written in a monastery on the Way of St. James. Furthermore, because of the fate of Roland, and of Charlemagne's military forays into Austurias and Navarra, Roncevaux became a focal point on the pilgrims' way. The Augustinian priory of Roncevaux, founded in the thirteenth century, had been (and still is) a high place of commemoration for Roland, Olivier and the other ten predominant knights that had fallen during the battle. The nearby Capilla funeraria del Sancti Spiritus, built, too, in the thirteenth century, according to legend, had been erected in memory of the twelve warriors, for it was there that Charlemagne had them buried. It was on the grounds of the chapel that Roland, in a fit of anger, splintered his sword, Durandal. In fact, the chapel was renamed Capella Carlomagni. Be they yarn-telling or historical documents, the heritage and memory of the battle were preserved in Spain: in Roncevaux a commemorative stone stands to honour this mediaeval event.

The Chanson de Roland was not only born and circulated in Spain, it also influenced the Spanish juglares (minstrels) and clergymen who sang, composed and copied El Cid, el Cantar de Roncesvalles and Rollan a Saragossa. We shall not repeat what Ramon Menéndez Pidal has so thoroughly researched in this fascinating transcultural field. There are, 
none the less, several points that I would like to expose at a narratological level between the Song of Roland and El Cid.

R. Menéndez Pidal stated that there are two sorts of borrowing: 'imitación immediata' (immediate imitation) and '... resultas analógicas generales de la fraternidad de las dos lenguas y literaturas' (... general analogical results due to the fraternity of the two languages and literatures). The Spanish erudite:... 'reconciéndose en el Cantar un fondo de tradición poética indigena y une forma algo renovoda por la influencía francesa' [11] (... acknowledged in the Cid a fundamental indigenous tradition and a form somewhat remodeled by French influences). Indeed, the formulaic style of the Cid is beholden to the 'septentrional' jongleur style of oral execution as well as the 'chivalric' vocabulary that constructs the iterate formulae, yet its themes and the form of its themes are truly of mediaeval Spanish stamp.

There is a salient feature of the two epic narratives that not only demonstrates their analogical narrative techniques but perhaps more important still, the gesture (geste) that triggers the dramatic tragedy of both tales: laughter.

In the Chanson de Roland it is Roland's humiliating laughter in Ganelon's face as they both stood before Charlemagne that provoked Ganelon's anger and weaved the plot to betray Roland to the Saracens:

'Guenes respunt: Pur mei n'iras tu mie ! AOI

Tu n'ies mes hom ne jo ne sui tis sire.

Carles commandet que face sun servise,

En Sarraguce en irai a Marsilie.'

(laisse XXI, verses 295-299)

'Quant l'ot Rollant, si cumençat a rire. AOI

Quant ço veit Guenes que ore s'en rit Rollant,

Dunc ad tel doel pur poi d'ire ne fent;

A ben petit que il ne pert le sens.'

(Laisses XXI and XXII, verses 302-305)

'Ganelon answers: You will not go instead of me ! AOI

You are not my vassal and I am not your lord.

Charles commands that I do his service.

I will go to Zaragoza to Marsile.

When Roland hears him he begins to laugh. AOI

When Ganelon sees that Roland laughs

He feels such pain that he is ready to burst with anger.

Little is needed before he almost loses his mind.'

It is not Ganelon's anger (anger is not a gesture) but Roland's laughter that provokes Ganelon and sparks the drama to come: the disastrous battle, Roland's death and Charlemagne's execution of Ganelon. Now we read a similar gesture in El Cid, Cantar III, strophe 112:

'Ferran gonçalez no vio dónde retirarse, ni habitación abierta ni torre;

se metió bajo el escaño, tal fue su temor;' [12].

(verses 2286-88)

'Fernando González not seeing any where to hide himself, neither in hall nor in tower; took refuge under a bench, fraught with fear.' (My translation).

The Cid subdues a lion that had escaped from its cage. In its flight it had terrified the putative manly Fernando Carrión, one of the Cid's future sons-in-law, he hiding in fear under a bench lest the lion feed on his flesh. Because of his cowardly gesture, and the Cid's heroic one, he became the laughing stock of the Court: 'Non habéis visto tales burlas como corrían el salón' [13] (You couldn't imagine the mockery that sped over the court.) It is this mockery (burla) that triggers the Carrión brothers' vengeance against the Cid's two daughters and the Cid's wrath against them, although, unlike Charlemagne's execution of Ganelon, he does not have the brothers put to death.

It goes without saying that the Chanson de Roland owes much of its European prestige to Spain in the same way that the Spanish El Cid owes much of its prestige to the Chanson of Roland. A dual narratological reciprocity that truly puts into relief mediaeval transculturation and intertextuality, forged like linked mailcoats due to their shared History, and to the oral and written compositional values that interlocked regions to one another. It is these overarching compositional values that little by little laid the transnational foundation of the poetic koinê.

This being said, Roland's and Charlemagne's reputation in mediaeval Spain has not been entirely drawn from the battle at Roncevaux as depicted in the Chanson de Roland. This is clearly shown in the twelfth century (1118-1185) poem Rollan a Saragossa, a 1,410 verse poem which narrates Charlemagne's siege laid before Zaragoza, Braslimonda's love for Roland, and Roland's and Olivier's profound fellowship and combat prowess in defending each other during the heat of sundry battles. Carlos Alvar pointed out that: 'Roldán quizás no estuvo nunca en Roncesvalles, ni se acercó en toda su vida a Zaragoza, pero sus vínculos con Carlomagna y la aureola que rodeaba su origen eran suficientes para que se considerara el más importante de los nobles caídos en la emboscada pirenaica;... [14] (Perhaps Roland was never in Roncevaux, nor had he ever come close to the city of Zaragoza in his whole life, but his relationship to Charlemagne and the aura that surrounded his origins were sufficient enough to consider him as the most important noble to have fallen at the ambush in the Pyrenees) (My translation). Carlos Alvar concludes that: '... parece clara la existencia de una épica provenzal, independiente de la francesa en muchos aspectos, con temas propios que rara vez llegan al norte' (page 92) (... it appears clear that there existed a Provencial epic, independent of the French epic in many aspects, with its own themes which rarely come from the North) (My translation). This conclusion coincides with R. Menéndez Pidal's own observations apropos El Cid.

Similarly with the Cantar de Roncevalles. A few words will suffice. Written in the Navarro-Aragonese dialect, a hundred verses have been preserved of the initial 5,500, according to R. Menéndez Pidal. [15] In eight strophes of unequal assonanced verses ranging from five to sixty-four, Turpin and Charlemagne lament the lose of Roland, of Reinaldos de Montalbán and of Olivier as they lay dead on the battlefield at Roncevalles. Certain stock formulae such as Charlemagne 'tugging at his beard' when displaying great sadness: 'por las barbas tirare' (strophe III, verse VII) or 'por las barbas floridas bermeja sayllia la sangre;' (strophe III, 
verse VIII) 'from his blooming beard (barbe chenue?) red blood sallies forth', appear to draw literary inspiration from the French poem. Nevertheless, if the narrative does indeed evoke the protagonists of the French poem: Roland, Charlemagne, and Olivier, the substance of it draws from both a Spanish tradition of story-telling and the written documents housed in various monasteries. In light of this evidence, the Rollan a Saragossa and El Cantar de Roncevalles fit nicely into the mediaeval western koinê for two reasons: first, they are perfect examples of poetic and dramatic intertextuality; texts that echo the initial voice of the minstrel and the rigorous hand of the interpolating clerk. Second, they had originally sprung from the lands upon which Roland and Charlemagne had tred, hence of whose memory the people of those lands sang and lamented. The Spanish and Navarro-Aragonese versions also point out an important aspect of the mediaeval western European koinê: it is not because the Oxford manuscript is the oldest variant that all the variants must have necessarily grown out of that version. The Songs of Roland (and Charlemagne) were sung throughout the western koinê in their diverse vernaculars, where gradually their first written compositions appeared, then recomposed and re-adapted. Compositional borrowing there evidently was, but there exists no sound evidence that the Oxford manuscript served as a prototype. The mediaeval western European koinê is a constellation of variants whose departure point are the Battle of Roncevaux, Roland and Charlemagne, but whose poetic and dramatic expression of that point varies from version to version...

\subsection{Nordico-Germanic Centripetal Forces}

'Ex hac igitur Scanzia insula quasi officina gentium, aut certe velut vagina nationum.' Jordanes [16] (It is this island Scanza, that one could call the factory of nations or the reservoir of peoples). (My translation).

The Nordico-Germanic influences in the Chanson de Roland are read at multiple levels: linguistic, juridical, ethnic, historical and narratological. The Frankish peoples migrating from Scandinavia (Gotland) had assimilated many other peoples of that region either through alliances or wars prior to their arrival in northern France, where Childeric I, Clovis' father, established a firm foothold at Tournai. Clovis defeated the Roman legions of Syagrius in 486, the Alemanni at Tolbiac in 496, and the Wisigoths in southwest France at Vouillé in 506. Thus commenced the long reign of the Frankish Merovingian and Carolingian kings whose mother tongues were Salic and Ripuarian until the enthronement of Hughes Capet in 987, whose mother tongue was French. Salic is part of the Low German language family which includes Saxon, Frisian, Dutch, Flemish and English. Ripuarian is of the High German language family which includes Bavarian and Alemannic.

The principal protagonists of the Chanson de Roland are of Nordico-Germanic descent: Hrodlant (Roland), which signifies 'the glorious one', Karlemagne (Charles the Great), who unified Germany by assembling the großstämme 'tribes' and who spoke Theodisca, first recorded in the Serments of
Strasbourg (842), and Ganelon whose name I shall shortly comment on. If we look at a map of Charlemagne's palaces, we observe that all but one were located in today's Germany: Aix-la-Chapelle (Aachen), Ingelheim, Cologna, Worms, Frankfurt and Wurtzburg; the lone palace in France was built in Metz (Lorraine). The other important summer palace is located in the Netherlands. [17] Charlemagne is not buried at Saint Denis with the other 'kings of France', but at Aix-laChapelle, where he was beatified in 1165. In 1966 an exhibition in Germany proclaimed Karl der Grosse as builder of Germany.

This being said, a statue of the Emperor on horseback in the forecourt or parvis of Notre-Dame Cathedral in Paris also points to a French or European Christian heritage and identity. It would be best to conclude that the historical and poetic figure of Charlemagne belongs to a Franco-Germanic geographic legacy because of the many conquests which built his empire at the end of the eighth and at the beginning of the ninth centuries. As to Roland, his 'French' statuary heritage has hardly fared better than the Emperor's. Like Charlemagne, Roland's effigy is barely visible in France. Conversely, his presence is found in abundance in guise of giant statues in Germany: Halberstadt, erected in 1381, Griefswald (1398), Brandeburg (1402), Bremen (1405-1410) [43] Perleberg (1498) [44], Leitmeritz (1539), [45] Stendal (1525) [46], Göttengen (date unknown). There are also two statues of Roland in Prague. The lone statue of Roland in France is found at Dole... [18].

Besides the giant statues, there are depictions of Roland's exploits on twelve stained glass windows at the Cathedral of Chartres. However, there are no statues or statuary jambs in church portals of Roland in France. There exist, though, statuary jambs of him at the Cathedral of Santa Maria Matricolare in Verona (Olivier is also depicted) and at the abbey of San Zeno, also in Verona, Italy, and at the Cathedral Vieja de Salamanca.

For the Germans, Roland has always symbolized justice, urban mercantile rights and free trade. His heroism is not gauged on his battle-lore against Saracens, but on his perspicacious mercantile role in favour of the expanding bourgeoisie of the urban centres of Germany, a similar role played by Etienne Marcel, the Prévôt (Provost) of Paris in the fourteenth century. It goes without saying that the 'French' Roland never enacted such a role in his feudal society.

It is perhaps due to this predominant presence of Roland and Charlemagne on German soil that so many studies of their poems have been produced by German scholars, and that the first translation of the Chanson de Roland was effected as early as 1132 by a Bavarian clergyman, the so called Konrad version, but generally referred to as Rulandesliet in Germany. I shall speak of this version in the second section. For now, I shall turn to the third major protagonist of the Song of Roland, the traitorous 'félon' Ganelon, for his name is also linked to Germanic lineage.

Philologically speaking, the name Ganelon has quite a notorious history: we first read of Guenes in the Vie de Saint Léger, where he has the inglorious role of being the saint's 
gaoler. Gérard Moignet believes that Ganelon might have been a sort of literary reincarnation of Bishop Wenilo, who in 859 was denounced by Charles the Bald for having betrayed him to Charles the Germanic. Whoever be the 'historical' Ganelon or Wenelon, his deeds have always been motivated by treachery and ill-will. It were as if Ganelon played the same villainous role from poem to poem as certain actors today play from film to film!

The incipit consonant cluster gu- $[\mathrm{g}]$ evolved from the Germanic semi-vowel [w], whence his Germanic name Wanilo or Wanilon. This infamous role has followed Ganelon straight to the recited verses and the pages of the Chansons de Roland. And whatever be the version of the poem, bards and monks inured themselves to maintain Ganelon in this immutably treasonous part.

Indeed, the Nordico-Germanic themes, and the vocabulary that couch them, construct the very drama of the poem. For example, knighthood by which the vassal-knight or the liegeman pledges fealty to his liege lord or overlord is epitomized by Roland and Ganelon who owe their allegiance to Charlemagne. Although not quite institutionalized in the Song of Roland, knighthood was a late mediaeval institution whose origins slowly emerged in the forms of rites and ceremonies in northern Europe: Scandinavia, Saxony, Normandy, Anglo-Norman England, and which evolved into the later religious ceremonial forms of dubbing or of adoubement during the twelfth and thirteenth centuries.

Knighthood was initially and fundamentally based on a moral contract between the vassal and his lord, be he an aristocratic knight or bishop to his king or queen, a tradesman or peasant serf to his count, duke, baron or marquis. The feudal society having gradually superseded the slave societies of Antiquity, its law-makers initiated a series of rights which evolved into an ever-widening sphere of social protection and individual rights as read in the Lex Salica (sixth century). [19] Vassalage provided the Frankish society with juridical laws that condemned overt slavery and its disrespect for the common human being; condemned, too, vendetta (faide) by the establishing of tribunes (mal) as read in the Lex Salica and in the Chanson de Roland. For example in the Lex Salica : '...in mallobero...' (article LVII) (or the mallobergio), and in the Chanson de Roland : 'Ben sunt malez, par jugement des altres,...' (v. 3855). (They (Thierry and Ganelon) challenged one another, according to the judgment of the others,...). Here the 'challenge' (malez) designates the place of legitimate combat within the limits of military and juridical feudal law.

The feudal social contract demanded both the serf or vassal and his liege lord the duty of honour and loyalty towards one another, conferring thus to each one social and individual dignity. As a vassal to his lord or king, a knight's honour was put into jeopardy if he failed to honour his duty, or if his honour had been besmirched. Roland's humiliating laugh before Charlemagne wounded Ganelon's honour, which consequently granted him the right to respond juridically, for that was his right as a knight bound to Charlemagne. Lawfully, Ganelon could have challenged Roland to a duel, and this would have been more appropriate in that particular situation rather than seeking revenge with the help of outside forces that not only killed a peer but a whole rear-guard. For this reason, albeit saddened by the execution of Ganelon, it was Charlemagne's lawful right to have him executed. But since Ganelon had always 'played the felonious role' there was no narrative reason to have him 'follow the law'. Moreover, if he had followed the law there would have been no story to tell...

Vassalage and the ceremonial rites incumbent upon knighthood also contributed to the Catholic Church's discourse on obedience to one's superior within the ecclesiastical hierarchy, which in turn reflected all men's obedience to God. The sacramental rites of knighthood in mediaeval society were auxiliary to the vertical cosmic and social chain that began with every man's absolute submission to God's will, the aristocratic seigniory to the king's will, the serf, be he craftsman, tradesman or peasant to his overlord's will. Along this immutable vertical chain every human being and living creature was accounted for. For the protection of animals, even bees, see the Lex Salica, articles II (theft of pigs), III (of animals in general), IV (sheep), V (goats), VI (dogs), VIII (bees), XXXVIII (horses) and in article VIII the theft of trees. It is upon this cosmic and social loom of which vassalage and knighthood were the weft and warp that weaved the decor and drama of the Chansons de Roland: Roland's laughter, the gesture of the thrown glove to the ground, Ganelon's treasonous act, the military jactance and physical stratagems, the warriors' battle-meeds and weapons, the final duels and Ganelon's execution.

In the Song of Roland, knighthood is illustrated by a vocabulary that describes its essential ethnic characteristics and poetics. In the Oxford manuscript, it is the NordicoGermanic vocabulary which describes knighthood in all its social facets, the foremost being the ceremony of adoubement or dubbing. From the etymon Dubban of AngloSaxon origin, we read in verse 713: "Escuz as cols e lances adubees" (The shields on their necks and their lances readied). Here 'adubees' means 'readied'. 'Adubez' in Old French signified 'prepare' or 'arm a knight'. Its use in the Song of Roland always has the meaning of 'to ready for combat'. Again for example in verse 2470: "Li adubez en sunt li plus pesant $\gg$ (The armed warriors are the heaviest). As Jean Flori has pointed out, the act of dubbing was not as yet either a technical gesture or an institutionalized ceremony in the Song of Roland. [20] Be that as it may, if the ceremony of dubbing had not as yet been institutionalized in the Song of Roland the two virtues for the 'preparation for combat' are clearly represented by gestures through the knights 'prouesse' (courage) and 'sagesse' (prudence): Olivier symbolizes both, whereas Roland only the first. For if Roland had displayed prudence he would have sounded his oliphant when Olivier pleaded for him to do so...

In spite of Clovis' baptism (496?) and energetic evangelizing of the Frankish population by the enthusiastic missionaries and monks of the nascent Catholic Church of Francia, much of the population had preserved their Nordico- 
Germanic practices: the belief in a personal God remained an abstract value for them. In the Chanson de Roland does not Roland die for his king, as knighthood honour and duty demanded of the vassal knight? In verse 2376, we read

"Envers Espaigne en ad turnet sun vis". (Towards Spain he (Roland) turns his face); that is, towards the scene where Charlemagne will carry out his double vengeance: against the Arabs and Ganelon. On the verge of death, Roland's face is not turned towards the Holy Land or Jerusalem. In fact, there is no indication that Roland dies for God at all: it is incumbent upon a vassal to die in honour of his king, alone. We read in verse 2380:

'De Carlemagne, sun seignor, kil nurrit'

'It was Charlemagne, his lord, who brought him up'

His is a vassal's death, one to be sung as an example (exemplum) or a model to be followed:

'Que Charles diet e trestute sa gent,

Li gentilz quens, qu'il fut mort cunquerant'

'That Charles and all his gentry say

That he died as a conqueror, the noble count'

(verses 2363/2364)

Roland dies first for his earthly lord, Charlemagne, then for his celestial Christian Lord. And by not sounding the oliphant, as Olivier so indefatigably implored him, he dies so that vengeance can be meted out, and his song be an epitaph to all that is grand and noble ! Jean Flori has expressed the loyalty of knighthood quite nicely: '... concierne más bien a la fidelidad de los vasallos al rey, de los cabelleros a su señor, y a los limites de esta fidelidad' [21] (...concerns more the loyalty of vassals to their king, of knights to their lords, and the limits of this loyalty.) (My translation) Indeed, the limits of this feudal loyalty are engraved in Roland's death, for the song to be sung about his death must neither tarnish his memory nor that of his companions. It is a song destined for Charlemagne... for story-tellers and their audiences... for posterity.

To comment on the hundred or so Nordico-Germanic etyma of the Chanson de Roland has already been done. [22] Nevertheless, certain linguistic details are interesting to expose because they disclose the vacillation between the Nordico-Germanic and the Gallo-Roman elements of the poem, thus truly reflecting the interwoven relationship between the two preponderant cultural realities of the mediaeval Frankish society. For indeed, these elements do not vie in any struggle for dominance, but blend rather nicely in that mediaeval mixtorum alteratorum unio.

The orthographic fluctuation between the incipit Germanic ' $\mathrm{k}$ ' as opposed to the Latinized ' $\mathrm{c}$ ' or ' $\mathrm{q}$ ' in words like Karlemagne/ $\mathrm{C}(\mathrm{h})$ arlemagne and the coordinating conjunction 'ki/qui' indicate scribal hesitation because both bards and scribes belonged or identified themselves to both Nordico-Germanic and Gallo-Roman cultures. However, kar (for) is never written in a Latinized form, 'car' as it was and is written in Middle and Modern French. There are two cases in the Chanson de Roland of possible palatalization of the incipit consonant cluster in the name Charlemagne. In verses 1242 and 1843, where it is written 'Charles', in which case the ch- cluster could be pronounced [ $]$ ]. If this were the case, however, the scribal interpolations would have had to be effected during the thirteenth century, a belated interpolation for the Oxford version.

As to the Germanic semi-consonant or vowel [w], which evolved into the voiced $[\mathrm{g}$ ] in words like WERE $>$ guerre (war), WAIDANJAN > gagner (win, earn), WARDON > garde (guard), etc., we find very few remnants of this phoneme in the Chanson de Roland besides Willalme (v. 3938) instead of 'Guillaume', perhaps due out of onomastic respect for William the Conqueror. We also find another orthographic fluctuation between wigres (vs. 2075 and 2156) and guivres (v. 2544), both of which have been interpreted as 'arrows, darts'. They are not distinct weapons. On the other hand, there exist several words in which the phoneme [w] has been conserved in an intervocalic position: ewe [wo] (water), for example in verse 2758, pronunciation which evolved into today's eau [o]; (in other poems 'ewe' meant 'river' as in Marie de France's lay Lanval et Yonec), liwes [ljw] (place) > lieu [ljø] (v. 2161) and siwant [suiwā] (following) $>$ suivant [suivā] (v. 2649). These mediaeval French spellings are constant throughout the poem. The grapheme [w] existed in Latin words, pronounced as [v]. Yet, it was the NordicoGermanic nations: Franks, Burgundians, Wisigoths and Ostrogoths that introduced the incipit ' $w$ ' into the evolving vernaculars.

As to the aspirated [h], reintroduced by the NordicoGermanic migrants into the Latin speaking populations of southern France, after its expiration had declined in the later periods of Latin, we hear the aspirated sound in words like halte (v. 3641). The ' $h$ ' of haut (high) is still heard: haut in the definite article/noun combination is written 'la haute (montagne)' and not 'l'haute'*; phonetically the [h] is heard, [lahotə] and not [lotə]*. All French words of NordicoGermanic origin still preserve the sound of the incipit aspirated ' $h$ '; for example, heaume (helmet) 'le heaume', [lo'om] and not [lom]*, haie (hedge), 'la haie', [la' $\varepsilon]$ and not $[1 \varepsilon]^{*}$, hache (hatchet/axe) 'la hache', [la'al] and not [la $]^{*}$, honte (shame) 'la honte', [la's̃t] and not [lõt]*, etc. The incipit ' $h$ ' in words of Latin origin such as homme (man) or hôte (host) are mute, thus necessitating liaison: 'l'homme' [lom] and not 'le homme'* [ləhっm]*, l'hôte [lot] and not 'le hôte'* [ləot]*. Many of the Nordico-Germanic etyma of the Chanson de Roland beginning with the phoneme [h] no longer exist in Modern French; for example, hanstes (spear) (v. 3080) and haitet (haste) (v. 1693). Others such as hostage (v. 679) gradually lost the aspirated [h] during the Middle French period. Today it is written 'otage'.

During the end of the nineteenth century and well nigh into the twentieth, French and German philologists and historians had waged terrible battles to win the Chanson de Roland over to their side: battles that, indeed, can be philologically stimulating. However, when these battles assume a cavalier treatment, analyses can be clothed in a warped and biased partiality that irritates more than stimulates, intellectually. Perhaps the poet Ludwig Uhland had best resumed the Nordico-Germanic and Gallo-Roman symbiotic alchemical 
process of the Song of Roland:

'un esprit germanique sous une forme romane' [23]

'a Germanic spirit in romance form.'

As I see it though, this formula remains dualistic in substance, whereas the mediaeval formula, mixtorum alterorum unio is monistic in substance, and thus characterizes much more precisely the essential nature of the Chanson de Roland. In other words, the spirit may be Germanic or Nordico-Germanic, however, there is also a Gallo-Roman spirit to the text. Similarly, the form may indeed be Roman, but also, to a certain extent, NordicoGermanic. And for this very 'hybrid' reason, I believe, as do Margaret Jewett Burland [24] and Sharon Kinoshita, [25] that the Song of Roland is surely European in nature and function, unfettered to any nationalistic appropriation or patriotic expropriation, be it linguistic or ethnic. The Chanson de Roland is not a mere reservoir of Germanic legends, rising from the mists of mediaeval pagan Teutonic Germany, recited from minnesinger to minnesinger until its written version. [26] Nor is it a chef-d'oeuvre of some scholarly author, exercising his literary talents for an aristocratic audience as Joseph Bédier, amongst others, had declaimed.

Out of the cauldron of songs, stories and legends of the migrating Nordico-Germanic peoples as they settled amongst the scattered communities of Gallo-Romans emerged the Chanson of Roland. How could a mediaeval epic narrative be of a single cultural fount when the fount itself had been a coalesced compound of several different origins? The frontiers of western Europe owe their remote contours by this Encounter between the nomad and the sedentary, an oral culture and a written one, a pagan tradition for the most part and a somewhat superficially Christianized one. Their Encounter commenced the slow but steady integrating and assimilating process out of which the Chanson de Roland had been spawned.

\subsection{The Western European Poetic Koinê of the Chansons de Roland: The Centrifugal Itinerant Forces}

The assimilated elements of the Nordico-Germanic and Gallo-Roman cultural Encounter produced the many versions of the poem that were either recited or written amongst communities which were gradually tracing their own linguistic and ethnic territories: territories such as Northumbria, East Anglia, Wessex and Mercia in England, Geatland, Cwenland, Gotland and Vinland in Scandinavia, Navarra, Aragon and Catalan in Spain, Burgundy, Gascogne, Brittany, Normany and the Aquitaine in France, Frisia, Austria, Saxony, Thurgingia and Bavaria in Germany and the March of Verona and Lombardy in Italy. These linguistic and ethnic territories comprise the mediaeval poetic koinê of western mediaeval Europe, now because of the poetic presence of the Chansons de Roland amongst the populations, now because of the prolonged martial and/or diplomatic contact with Charlemagne's Frankish armies. It would be without exaggeration to say that the Chansons de Roland provided a literary model to laud and promote that high period of empire-building by Charlemagne. It is no happy accident that the Chansons de Roland were eagerly recited and read during the Crusades; neither is it fortuitousness that Charlemagne's figure looms larger and larger in the poems, becomes more ecclesiastically elaborated under scribal extension, as if the Emperor's skirmishes and forays against the Saracens in Aragon and Navarra of the eighth century had metamorphosed into the Crusaders' chivalrous exploits of the eleventh, twelfth and thirteenth centuries in the Holy lands. If Roland's death gave birth to the composition of the song, it was Charlemagne's military expeditions in western Europe and his charismatic figure that enlarged the spectrum of diffusion for the many versions throughout those war-worn lands. It may be said then, but with all due reserve, that Roland's laughter, heroic combat and death, and Ganelon's treason provided the trouvères, the bards and the minnesingers with the dramatic material for the centripetal forces, whilst it was Charlemagne's warring against the Saracens and his vengeance against Ganelon, the first being the historical enemy, the second the literary one, that furnished the itinerant material for the centrifugal forces.

Since I have already commented on the oldest text of the Chanson de Roland, the Oxford manuscript, I shall briefly enumerate the other versions in the order of their approximate dates of composition. [27]

The second version of the Chanson de Roland is called Venice $I V$; fundamentally it is a product of Orature, or in the words of Paul Zumthor: 'le lieu de résonance d'une voix' (The place of resonance of a voice) (my translation). It was housed in Saint Mark's library and is a melding of Anglo-Norman and Venetian linguistic features, the first undoubtedly memorized or copied, the second a translation (in the etymological sense of this word) or bardic improvisation. The verses are assonanced and rimed. Between the minstrels and the scribes' interpolations, a total of 6,011 verses were composed: 571 describe Ganelon's traitorous act, 660 Charlemagne's siege at Narbonna, and the prayers -several verses in the Oxford version- are lengthened to a monotonous litany. The Venice IV version, albeit of oral fount, concentrates more on Charlemagne's exploits and Ganelon's betrayal than Roland's deeds, which can be explained by the impact of Charlemagne's conquests and personality in the northern territories of mediaeval Italy and by the Church's crusade against disloyalty and sedition to one's L (1) ord.

The third version version, called Châteauroux (also called the Versailles manuscript), is a completely written composition, as are all the others that follow. It dates from the thirteenth century and contains 8,330 verses: 800 to depict Aude's torment and tears when learning of her lover's death. (In the Oxford version the bards grant her a mere 28 !) The order of the laisses (strophes) does not correspond at all with the first two versions, as if they had been purposely severed from the principal thread of the poem in order to create a warren of secondary narrative scenes, many of them inflated to a dull prosody, making comparison from one version to another a convoluted effort. This last remark holds true for the final five versions. There is no doubt that the variability, both in length and style of all these written 
versions bears not only the linguistic discrepancies and ethnic traits of the scribes but also their political (which implicitly implies religious) motivations at the time of composition. Charlemagne's role becomes more and more predominant, and several figures who were 'extras' in the Oxford version, for example, Aude, in other versions are accorded larger parts, oftentimes falling into a more prosaic vein.

Similarly with the fourth version, Venice VII, also a purely written composition of the thirteenth century. It contains 8880 riming verses, though without assonance. On the other hand, contrary to Venice $I V$, the text has not been 'Italianized'. Many new episodes have been added which transform the parataxic rhythm and the formulaic expression of the original poem into a more narrative one. It reads more like a novel than a poem. Undoubtedly, Venice VII drew inspiration from the written form of Venice $I V$, however, without taking into account any dimension of its oral properties. Indeed, a myriad details bury the kernel of the drama of the text: Roland's death. Significant, none the less, is that Ganelon becomes a feeble coward. No longer is he the noble knight of the Oxford version, highly esteemed by Charlemagne; esteem which casts in relief his execution at the end of the original poem, for Charlemagne's tears are genuine, and his regret, great: the Emperor has lost two fine warriors. As one can observe, from version to version the Poetics of Orature gradually decline to scriptural verbosity.

The Paris version was also written in the thirteenth century (1265-1290) in a northern French dialect. It is puffed up with long lines of prayers and Charlemagne's pilgrimage to Roncevaux. The whole narrative comprises 6,830 verses. The reader of the Paris version must wait until verse 332 before recognizing the first verses of the Oxford version. This version was edited by Francisque Michel in 1869 .

The sixth version is called the Lyon manuscript, which contains only 2,933 verses, mostly prayers in Latin and a long interpolation of the life of Saint Maguerita. Burgundian linguistic traits mark the Lyon manuscript since the text was written in the territories populated by the Burgundian peoples who had migrated to that area of France during the fifth century. This version has left very little space for the original message of the Song of Roland, which has been substituted for prayer and hagiographic material, indicating quite clearly the transmutation of a tale of chivalry into an ecclesiastical scripture of hortation and appeal. The scribe, however, did copy thirty verses of Olivier's pleadings to Roland to sound his olifant.

The last 'full' version of the Chanson de Roland is the Cambridge manuscript. It contains 5,705 verses of which only 766 have been extracted from the Oxford text. It was composed in the sixteenth century. Unlike the other written texts, the scribes here attempted to recreate a mediaeval ambiance by the use of archaic spellings, for example, espee (sword) and esploite (exploit), the letter 's' of the incipit consonant cluster 'es-' having disappeared during the thirteenth century. It were as if the scribe or scribes in their belated effort sought to erode the distance between the 'original' text and their recomposed one.
There exists a fragment of the Chanson de Roland called the Lorraine manuscript, which only contains 337 verses. These verses concord with Venice IV (laisse 166), with Châteauroux (laisse 216), with Venice VII (laisse 204), with Paris (verse 118) and with Lyon (verse 75). The fragment was edited by Francisque Michel and published by F. Guénin in 1850. It is quite a feat of intertextuality, which demonstrates the itinerant force of all the versions, and the zeal and pleasure of poets and scribes to elaborate, inflate, conflate, transform and propagate the deeds and misdeeds of Roland, Charlemagne, Ganelon and all the other dramatis personae of the Chansons de Roland.

Finally, [28] I must finish this survey with a brief word on the Konrad manuscript (the Rulandslied: Lay of Roland), translated or adapted by a Bavarian monk or priest in 1132 . The Bavarian must have had access to the Oxford manuscript and Venice IV for his translation collates to both versions quite nicely. This being said, he also added sections, for his adaptation contains 6,092 verses, and although it does follow the original plot, the Bavarian eliminated much of the lyrical variants, excluding, too, the repetitions and stock formulae. If the laisse form and assonance sound pattern were preserved, much of the original parataxic syntax structure was substituted for a more hypotaxic one, and thus became a more narrative reading. The adapted poem reads more like a novel or an account of the battle of Roncevaux. The translator divided the battle into three parts as if the adaptation were an academic demonstration. As if his translation explicated an historical text to read by an educated audience. On the other hand, albeit it be a mere detail, if the adapter had indeed eliminated much of Charlemagne's tearful scenes and 'grey beard' (barbe chenue) tuggings, in one particular scene he had the Emperor cry bloody tears, a poetic formula or kenning that can be read in Das Nibelungenlied. [29] The Konrad manuscript or Rulandesliet, attests to the translator's efforts to diffuse the battle of Roncevaux not as some piece of poetic prowess to be read aloud, but as an historical document which linked the battle and the warring exemplars to a culture that the Germanic communities of the twelfth century would not only appreciate but to which they would identify themselves. In this sense, it appears to me that it also bears the stamp of Roland's and Charlemagne's European character.

To recapitulate: the Battle at Roncevaux occurred in 778 . The distant beginnings of Roland's death and Charlemagne's revenge circulated throughout western Europe between the seventh and eleventh centuries in the form of cantilènes, word to ear reportings, legends, bardic recitations, etc. The first composed versions were written in the twelfth century: Oxford (1130), Rollan a Saragossa (1118-1185), Rulandes Liet (1132) and the Cantar de Roncesvalles (twelfth century); the second oral fount was compiled in the fourteenth at Venice, and the six other versions, all purely written compositions, were composed during the thirteenth, fourteenth and fifteenth centuries. This is quite a cultural exploit, and reveals the wide range of Roland's and Charlemagne's charismatic personalities and heroic feats. 
Reveals the steady flow of the centrifugal forces that diffused the oldest versions far and wide over such vast and distinct territories. It were as if Roland's bold struggle and defeat and Charlemagne's revenge and forays inspired both bards and scribes to create a sort of poetic continuum, to bear a poetic and political message throughout territories that indeed claimed distinct linguistic, ethnic and cultural traits, but at the same time shared very deep underlying and overarching values. Values that Sharon Kinoshita has termed as the 'collective identity' of the Frank. It goes without saying that the original message became less and less poetic as the versions multiplied, more and more inflated with ecclesiastical convention and legendary inaccuracy. I shall insist once again that I am not insinuating that the Oxford manuscript be the 'genesis' or the 'prototype' of all the itinerant versions. As Sharon Kinoshita has clearly shown the Oxford manuscript did not generate the 'narrative tradition' of the Roncevaux versions. A detailed intertextual relationship of these versions is much too complex to be taken up here. The Oxford version, however, being the oldest of the vernacular versions, fragments of it reached the distant regions where both Frankish and Norman military and diplomatic activity were the most intense.

Less and less hybrid or polyphonic because the oldest fragments had been drawn from the initial Encounter between the vying ethnic forces of the nomadic NordicoGermanic migrants and the sedentarized Gallo-Romans. In the written versions we hear less the throaty cries and wails of high-minded individuals, the clashing of consonants and armour, see less their colourful gestures, the dragons painted on the Saracens' shields, the green grass ruddy with dusky blood. These doughty figures lose their poetic, exemplary aura in the written versions. Their dauntless vigour pines, henceforth to open hortatory solicitations because of the growing anagogical needs of ecclesiastical enlargement in the wake of Charlemagne's ever-broadening empire...

Whatever the poetic value of these versions may be, if they did not actually trace the contours of a mediaeval western European poetic koinê they certainly circumscribed and confirmed those contours that had been tentatively traced since the Oaths of Strasbourg in 842 .

\section{Conclusion}

\section{Mixtorum Alterorum Unio}

As I see it, the Chansons de Roland left their indelible traces in mediaeval western Europe because the poetic form and the political message that they bore, albeit in varying discursive forms, were the founding values of a developing mediaeval western European civilization. I am certainly not saying that the Chansons de Roland founded this civilization, but they did reveal an undisputed motivation or movement towards unification.

This conflated energy of narratological continuum can be visualized by the centripetal and centrifugal forces that composed and transmitted the poems in the figure of a sandglass through which very diverse elements flow, integrate and assimilate into a whole, only then to be dispersed and newly reunited in various other poetic forms. This dual force, over the centuries, gave birth to the Chanson de Roland, and again, over the centuries, to the mediaeval western European poetic koinê, a territorial and discursive delimitation, traced by the multiple versions and translation-adaptations of the Chansons de Roland.

The Chanson de Roland is a hybrid composition of heterogeneous elements as is the koinê from which all its versions drew inspiration. For a koinê is not a common language but a common discourse. The Chanson de Roland like Old French is comprised of a myriad discourses because comprised of the myriad distinct voices that penetrated and settled the territories of mediaeval France. Each voice distinct yet harmonized by the process of assimilation. Roland's, Charlemagne's, Ganelon's, Turpin's, Olivier's and many other voices are distinctly heard in the Oxford version. However, their voices, as the versions become more literary, more scriptural are transformed into quite another discourse, for the most part ecclesiastical and hagiographic. And it is these transformed discourses that circumscribed the frontiers of the koinê, ones that lauded and sang Charlemagne's expanding empire, his devotion and generosity to the Church, his efforts to educate the clergymen.

As I stated above, many philologists and historians of the late nineteenth and early twentieth centuries ignored the cross-cultural mosaic figurations of the Chanson de Roland, even casting opprobrium on the ethics of the text. A few telling examples will illuminate my point. Ferdinand Brunetière wrote:

'Je ne vois que des hardis aventuriers, violents et sanguinaires, qui ne croient qu'à deux choses au monde: la trempe d'un glaive enchanté, la vertu d'une bonne armure. Et rien d'humain ne bat sous cette épaisse armure, rien que l'intraitable et risible orgueil du barbare et son arrogante confiance dans la vigueur de son bras' [30]

(I only see hardy adventurers, violent and bloody, who believe only in two things in the world: the steeliness of an enchanted sword, the virtue of good armour. And nothing human beats under this thick armour, nothing, only the uncompromising and laughable pride of a barbarian and his arrogant confidence in the vigour of his arm). (My translation)

Note the word 'barbare'; in other words, 'Teutonic'. It is evident that Brunetière did not disguise his loathing for anything Germanic. His anti-German stance is understandable since he wrote his dissertations six years after the defeat of Napoleon the Third's French armies at Sedan. The erudite's animosity towards the Teutons drives deep into the very core of their language:

'La langue est dure, dure à l'oreille, dure à la gorge, et jusqu'aux plus belles pensées du monde, elle les marque de son caractère de barbarie [...] où les consonnes se heurtent et s'entrechoquent avec un bruit de mauvais allemand'.

(The language is hard, hard for the ear, hard for the throat, and even the most beautiful thoughts of the world have been branded by its barbaric character $[. .$.$] where the consonants$ 
collide and clash with the noise of bad German).

It were as if the German language epitomized all that is 'clangorous' in the Chanson de Roland. Indeed, the soundscape of the Chanson de Roland reflects the steel-like, barbaric character of the Germanic spirit when meditating upon the world, whilst the clashing of German consonants resounds of the clashing of German ordnance. Brunetière essentializes the German language because he confuses language and discourse; because he likens a people to its language, and thus to the poem itself.

Brunetière questions his ancestral identity: Were we of Germanic extraction?

'On peut regretter, mais on ne saurait nier que nos ancêtres aient parlé, du $\mathrm{X}^{\circ}$ au $\mathrm{XVI}^{\circ}$ siècles "la langue la plus barbare; rude comme leurs mœurs et grossière comme leurs appétits'

(One can regret, but should not deny that our ancestors, between the $\mathrm{X}^{\circ}$ and $\mathrm{XVI}^{\circ}$ centuries, spoke "the most barbaric of languages; harsh like their customs, vulgar like their appetits).

Regrettable that it be, Brunetière was obliged to admit that his ancestry did have tinges of Teutonism, and conceded because of this that the language of the Chanson de Roland was only in its embryonic stages:

'Évidemment ce jargon, demi-latin, demi-germanique encore, est toujours en travail d'enfantement d'une langue digne de ce nom.'

(Indeed this jargon, half-Latin, half-Germanic is still a language in the pangs of birth, worthy of this name).

The French language overcame the pangs of birth and exceeded mediaeval jargon to become a gem of Classical purity. Notwithstanding Brunétière's acrid convictions, the Chanson or the Chansons de Roland does (do) not belong to this myth of race/language purity but to the historical reality of integrated and assimilated discourses and forms.

Joseph Bédier, with less bitterness and more poetic prowess, showered much praise upon the Chanson de Roland, and went so far as to state that it: 'signale un redressement de l'esprit français, œuvre d'intérêt national, œuvre de résurrection' (marks a recovery of the French spirit, a work of national interest, a work of resurrection). (My translation).

Bédier ignored the Chanson de Roland's 'birth pang' vitiations and concentrated his politically motivated ardour on the historic dilemma which followed the defeat at Sedan. He was convinced that at Roland's and Charlemagne's behest France would overcome her disgraceful defeat, and would patriotically rise again out of the fumes of shame and humiliation. The studying of the Chanson de Roland in secondary schools and its singing in classes would 'resurrect' the memory of Roland and Charlemagne, would 'resurrect' the hope that they would come to France's succour. For according to Bédier, the Chanson de Roland was 'notre génie national' (our national genius), 'nos épopées nationales' (our national epic tales). Bédier, unlike Brunetière, treated Roland as if he possessed some sort of patriotic trait of character, and believed the Chanson de Roland to be a veritable monument to French culture; an exclusive monument not to be shared or pillaged, nor to be stolen from the French by the Germans.

Be it a corrupt, awkward piece of work, written in some adulterated dialect, thereby associating it to the Germanic feudal system, or a piece of heroic patriotism, the Chanson de Roland had always been confined to the limits of French or German geo-political borders, whereas the very matter and form of the poems, and the fact that they had been recited and written well beyond those two circumscribed borders, point to a very different compositional and geographic reality. The problem lies basically in the analysis of the poem, judged always through the prism of language and not through discourse. The Song of Roland is a myriad of discourses; that is, of voices, melded homogeneously, yet each discourse or voice is independently heard or read, be they the diverse discourses of the itinerant minstrel or the scribe's interpolations. There can be no convergence of elements without divergence, nor can there be divergence without convergence. As to racial or literary purity, this is a nationalist myth, ideologically motivated.

The Art of Discourse is both oral and written, and the Song of Roland possesses both, admirably. It is neither a monolithic voice nor one of sole authorship. It is composed of many discursive voices that were assimilated through a long process of coalescence, and whose inexorable flow spread in wider ripples the poetic and political message of the original over the once war-torn lands by Charlemagne, there converging with other voices and discourses until each version reached its own fine literary blend, bearing with it the plot, the dramatis personae and themes of the original, albeit in varying forms in accordance to the poetic capacities and political imperatives of its own region. In sum, the Chansons de Roland are works of Orature. To avoid any ambiguity, I am aware that Charlemagne never stepped foot in England much less conquered it. As I mentioned above, the two versions of the Chanson de Roland housed in England owe their geographic presence to the invading Norman armies. This being said, Charlemagne's relations with England were considerable : In 809 he helped restore to the throne king Eardwulf of Northumberland who had been chased away by his subjects and had taken refuge at his court, and Charlemagne had summoned the erudite Alcuin of York to his court to be chief counselor on pedagogical matters.

Because of its large-scale geographic width and breadth, the mediaeval western European koinê reflects the poetic and political stature of the Chansons de Roland.

To conclude, I would say that the Chansons de Roland founded a poetic discourse [31] to which the mediaeval populations of western Europe identified themselves: the betrayal and heroic death of a grand knight, the vengeance carried out to remove the shame of that betrayal, the victory over the Saracens by an Emperor who had carved out an empire of which Germanic royalty and knighthood and the Catholic Church became now the pillars of its foundation now the military and spiritual impetus to its European expansion. [32] This mediaeval discourse composed and diffused the Chansons de Roland [33]. 


\section{References}

[1] Saint Thomas of Aquinas, Summa Theologica, Benziger Bros. Edition, 1947. Saint Thomas of Aquinas believed that the elements of the 'mixture' needed to be emptied of their properties before being integrated into a whole (unio), whereas, Duns Scotus refuted this belief and postulated that however assimilated, the elements in question had to retain their original properties in order for the demonstration to be analysed and repeated. I am in full agreement with Duns Scotus.

[2] Or, 3,997 according to other versions. See J. J. Duggan, La Chanson de Roland/The Song of Roland: The French Corpus, Brepols, 2005. Joseph Duggan, Formulaic Style and Poetic Craft, California, University Press, 1973. See also, Jean Rychner, La Chanson de Roland, Genève, Droz, 1955.

[3] Gérard Moignet, La Chanson de Roland, Paris, Bordas, 1969. For this text, and for my article in general, I refer to Gérard Moignet's excellent translation and study on La Chanson de Roland.

[4] Andrew Taylor, Textual Situations, U. S. A., University of Penn State, 2001, and Ian Short, Manual of Anglo-Normand, Oxford, Anglo-Normand Text Society, 2013.

[5] M. K. Pope, From Latin to Modern French, Manchester, Manchester Press, 1952 pp. 120-135.

[6] W. W. Skeats, Etymological Dictionary of the English Language, Oxford, 1983, page 430.

[7] José Maria de Miguel Lacarra, 'A propos de la route de Roncevaux et du Lieu de la bataille in Annales de Midi: Revue de la France Méridionale, Vol. 78, N 77-78, 1966. Translation Pierre Bonnassie.

[8] R. Abdal, R. M. Pidal, J. Favier, A. de Riquer, 'Carolmago en Roncevalles: un error militar viario', El Miliario, Nº1, 2005. They believe that: "Hoy se admite generalmente que en Roncevalles, los atacantes fueron gentes vasco-navarras, ayudadas seguramente por musulmanes zaragonzanos y pamploneses." "Today it is generally acknowledged that the ambushers at Roncevaux were Basques from Navarra, surely helped by Muslims from Aragon and Pamplona." (My translation).

[9] Alonso Dámaso, La Primitiva épica francesa a la luz de une 'Nota Emilianense' in Revista de Filología Española, XXXVII, 1953, pp. 1-94.

[10] Joseph Bédier, Les légendes épiques, Paris, H. Champion, 1967. (Three volumes). The Song of Roland is discussed in volume three.

[11] Ramon Menéndez Pidal, En Torno al Poema de Cid, Barcelona, 1970.

[12] Ramon Menéndez Pidal, Cantar de Mio Cid Vol III, Madrid, Espasar Calpe, 1945.

[13] Cantar de Mio Cid, verse 2307. Modern Version.

[14] Carlos Alvar, Roldán en Zaragoza: poema épico provenzal, Zaragoza, Disputación, 1978, page 13.

[15] Ramon Menéndez Pidal, 'Roncevalles, un nuevo cantar de gesta española del siglo XIII in Revista de Filología Española,
IV, 1917, pp. 105-204.

[16] Jordanas, De Origine Actibusque Getarum (The Origins and Deed of the Goths), 551-552. Jordanas was an Ostrogoth chronicler of the sixth century.

[17] Rosamond Mekitterick, Charlemagne, The Formation of a European Unity, Cambridge, 2008. She states that no palace, summer or winter, was more important than another.

[18] Jacques Stiennon and Rita Lejeune, La Légende de Roland dans l'Art du Moyen Age, volume I and II, Liège, 1967.

[19] Jean-Marie Pardessus, Lex Salica, chez August Durand Libraire, 1843.

[20] Jean Flori, 'Sémantique et société médiévale. Le verbe adouber et son évolution au XIIè siècle. Annales: Economie, Sociétés, Civilisation, vol. 31, No 5, 1976, pp. 915-940. And 'Les origines de l'adoubement chevalresque: étude des remises d'armes dans les chroniques et annales latins du 9ème au 13ème siècle', Traditio, vol. 35, 1979, pp. 209-272.

[21] Jean Flori, Cabelleros y caballería en la Edad Media, España, Paidos, 2001.

[22] Paul Mirabile, La Genèse de la Chanson de Roland, France, Voies Itinérantes, 1987.

[23] Gaston Paris, Revue des Langues romanes, 1860, page 385.

[24] Margaret Jewette Burland, Strange Words: Retelling and Reception in the Medieval Roland Textual Tradition, USA., University of Notre Dame Press, 2007.

[25] Sharon Kinoshita, Medieval Boundaries: Rethinking Differences in Old French Literature, U.S.A., University of Pennsylvania Press, 2006.

[26] George Fenwick Jones, The Ethos of the Song of Roland, Baltimore, John Hopkins Press, 1963 for the juridical elements read in the Chanson de Roland.

[27] Raoul Mortier, Les Chansons de Roland, Paris, De la Geste Francor, 1940.

[28] Margaret Jewette Burland, Strange Words: Retelling and Reception in the Medieval Roland Textual Tradition, ibid. She discusses the Occitan version of Roncevals as well as Châteauroux and the fifteenth century 'Galien restore' versions. I have studied neither the Occitan nor the 'Galien restore' versions.

[29] Danielle Buschinger, Le Curé Konrad, adapteur de la 'Chanson de Roland', Cahiers de Civilisation médiévale, Paris, 1983, pp. 95-115. The formula is: '.. ir vil leihten ougen vor liede weingten bluot.' 'From her eyes so clear she cried grieffilled bloody tears' (my translation). This mediaeval epic formula is also read in the Turkic epic tale Dede Korkut Kitab1 '... kara suzme gozlerin kas yas dolu.' '... her black,slit eyes filled with bloody tears' (my translation), and in the Chinese epic narrative $\mathrm{Ji} \mathrm{Bu} \mathrm{Ma}$ Zhen, Ji Bu Insulting the Enemy (Camp): (xuè lèi) 'bloody tears'. Iris Murdoch rehabilitated the mediaeval epic formula in her novel The Sandcastle: 'They sat looking down into the stubble. "Tears of Blood," said Felicity. This was an ancient ritual.' London, Penguin, 1957, page 143.

[30] Ferdinand Brunetière, Revue des Deux Mondes, Paris 1879, page 143 .

[31] Bernard Cerquiglini, La Naissance du Français, Paris, P. U. F., 2013. 
[32] Gerard J. Brault, Song of Roland: An Analytical Edition: Introduction and Commentary, U. S. A., Penn State Press, 2010.
[33] Claude Gauvard, Alain de Libera, Michel Zinc, Dictionnaire du Moyen Age, Paris, P.U.F., 2004. This dictionary is an extraordinary work for both general and detailed information concerning mediaeval life. 